\title{
Validation of the Extrinsic and Intrinsic Motivation Scale Among Beginner Badminton Child-Athletes
}

\author{
Yusuf Hidayat*, Burhan Hambali \\ The Faculty of Sport and Health Education \\ Universitas Pendidikan Indonesia \\ Bandung, Indonesia \\ *yusuf_h@upi.edu
}

\begin{abstract}
The aim of this study is to determine the factorial validity and reliability of the extrinsic and intrinsic motivation scale (EIMS) in badminton training context. The study involved 312 beginner badminton child-athletes aged 10-12 $\left(M_{\text {age }}=11.14\right.$; SD $_{\text {years }}=1.62$ ) in West Java. EIMS is an adaptation and modification of the sport motivation scale developed by Deci \& Ryan (2002) consisting of extrinsic motivation dimension (EM-D) and intrinsic motivation dimension (IM-D). The results of the analysis of internal consistency reliability obtained through Cronbach's alpha coefficient index $=.92(42$ items $)$, EM-D $=.88$ ( 24 items), and IM-D = .78 (18 items). The results of confirmatory factor analysis (CFA) for the factorial validity showed that there were 30 valid items (factor loading $(F L)=.52$ to .87 ) that consisted of $17 \mathrm{EM}-\mathrm{D}$ items $(\mathrm{FL}=.59$ to .86$)$ and $13 \mathrm{EM}-\mathrm{D}$ items $(\mathrm{FL}=.52$ to .87$)$. In accordance with the results of the analysis, 30 items constructing the EIMS are valid and reliable to measure the sport motivation of the beginner badminton child-athletes in badminton training.
\end{abstract}

Keywords-confirmatory factor analysis; intrinsic motivation; extrinsic motivation; bádminton; child-atheletes

\section{INTRODUCTION}

As a hypothetical construct, motivation is defined as "the internal and/or external forces that produce the initiation, direction, intensity, and persistence of behavior" [1], including behaviour in sport activities in which defined as a complex phenomenon where individual involvement in sport activities is driven by various and different types of motivation [2]. In the psychology and sport psychology research, motivation has become one of the most important areas of research [3-4], especially in physical activity during childhood and adolescence period [5].

There are a lot of theories that can be used to understand sport motivation, including self-determination theory/SDT as one of the most popular theories [6-7], especially in the field of sport and exercise psychology and known as a macro theory of sport motivation [8]. In SDT perspective, motivation is a multidimensional construction incorporating intrinsic motivation, extrinsic motivation, and amotivation. The three types of motivations are compiled in a hierarchical model of human motivation and known as the hierarchical model of intrinsic and extrinsic motivation that differentiate the autonomous motivation and controlled motivation [9].
The most autonomous type of motivation is intrinsic motivation that is related to individual involvement in an activity as a mean of gaining pleasure and satisfaction of their participation in the intended activity. Intrinsic motivation is constructed by three intrinsic motivation indicators including to know (TK-I), to toward accomplishment (TA-I), and to experience stimulation (TES-I). Extrinsic motivation is the most controlled motivation that is related to individual involvement in an activity as a media to accomplish external goals from the activity that consist of four indicators including external regulation (EXR-I), introjucted regulation (IJR-I), identified regulation (ITR-I), and integral regulation (IGR-I) $[1,10]$. The lowest type of motivation is amotivation, laid at the edge of SDT continuum, known as a total absence of motivation" [11], without motivation [12], learned helplessness [13], or a lack of intention to act [14].

Sport motivation measurement has been conducted in the wide range of diversity of research and different areas [2]. In the beggining, it was developed in France, replicated in England by Pelletier, et al. [15], by Martens and Weber in America [16], by Barkoukis, et al., in Greece [13], by PinedaEspejel, Alarcon, Lopez-Ruiz, Trejo, and Chavez in spanish [17], and revalidated by Pelletier, et al. [2,14], to measure the fifth or sixth grade students' sport motivation in physical education class [18], and athletes aged 11-13 year from 12 sport types in West Java [19], However, those measurements are still generic, arranged for different types of sport, and limited to elite and adult athlete. Meanwhile, the specific measurement for specific sport and beginner participants is still limited.

Based on the consideration of the characteristics of the participants as a beginner and child aged athletes, the diversity of motivation in sport participation, and the fact that badminton is an interesting and popular sport in Indonesia, this study focused on the factorial validity and reliability of EM-D and IM-D on beginner student-athletes of Badminton.

\section{METHODS}

\section{A. Participants}

312 Badminton student-athletes aged from 10-12 ( $\mathrm{M}_{\mathrm{age}}$ $\left.=11.18 ; \mathrm{SD}_{\text {years }}=1.9\right)$, including 30 student-athletes for limited trial and language validation $\left(\mathrm{M}_{\text {age }}=11.14 ; \mathrm{SD}_{\text {years }}=1.62\right), 282$ 
persons for empirical estimation $\left(\mathrm{M}_{\text {age }}=11.15, \mathrm{SD}_{\text {years }}=1.40\right)$, 124 beginner female student-athletes $\left(\mathrm{M}_{\mathrm{age}}=11.20, \mathrm{SD}_{\text {years }}=\right.$ $1.70)$, and 158 beginner male student-athletes $\left(\mathrm{M}_{\mathrm{age}}=11.22\right.$, $\left.\mathrm{SD}_{\text {years }}=1.80\right)$. Considering the inclusive criteria of the participants, including the involvement of beginner female and male student-athletes, the activity status in following practice and training in club or school of Badminton in West Java, and the period status in training participation ranged from 1-2 years, a purposive sampling was chosen as a sampling technique to be used in this research [20].

\section{B. Procedure}

EIMS was developed based on the SDT [6-7], by incorporating only intrinsic motivation dimension (IM-D) and extrinsic motivation dimension (EM-D). The EXR-I, IJR-I, ITR-I, and IGR-I indicators are constructed in EM-D, while IM-D was elaborated into TK-I, TA-I, and TES-I indicators. There are 42 developed items, including 24 EM-D items and 18 IM-D items. Each indicator was built from six items. Each item was written in a close-declarative form in three alternative answers, involving Agree (A), neutral (E), and disagree (NA). The score of each answer ranged from 1 to 3 . The analysis of the item was conducted on the data obtained from limited trial, language validation data were validated by three panel expert judgment (PEJ) of Indonesia language, The content validation data were validated by five PEJ personals, and the empirical validation data of 282 beginner badminton athletes aged 10-12 years were taken from 21 badminton clubs or schools in West Java. The data were gathered when the Bumi Siliwangi Universitas Pendidikan Indonesia Championship was conducted in July 2018.

\section{Data Analysis Technique}

The data from the limited trial and language validation test were analysed by using descriptive percentage analysis technique, while the Aiken's analysis technique formula was used to measure content validity [21], Confirmatory factor analysis (CFA) technique was used to estimate factorial validity [22-24), and coefficient Alpha Cronbach analysis technique was used to estimate the internal consistency reliability [25].

\section{RESULTS}

TABLE I. STATISTICS DESCRIPTIVE OF LANGUAGE AND CONTENT VALIDATION

\begin{tabular}{|l|l|l|}
\hline \multicolumn{1}{|c|}{ Item } & \multicolumn{1}{|c|}{ Mean \pm SD } & SE \\
\hline Item_1 & $4.29 \pm .95$ & .36 \\
\hline Item_2 & $4.57 \pm .53$ & .20 \\
\hline Item_3 & $4.00 \pm .82$ & .31 \\
\hline Item_4 & $4.57 \pm .53$ & .20 \\
\hline Item_5 & $4.43 \pm .53$ & .20 \\
\hline Item_6 & $4.71 \pm .49$ & .18 \\
\hline Item_7 & $4.43 \pm .53$ & .20 \\
\hline Item_8 & $4.14 \pm .69$ & .26 \\
\hline Item_9 & $4.29 \pm .76$ & .29 \\
\hline Item_10 & $4.14 \pm .38$ & .14 \\
\hline Item_11 & $4.57 \pm .53$ & .20 \\
\hline Item_12 & $4.43 \pm .53$ & .20 \\
\hline Item_13 & $4.57 \pm .53$ & .20 \\
\hline
\end{tabular}

Table I. Cont.

\begin{tabular}{|l|l|l|}
\hline \multicolumn{1}{|c|}{ Item } & \multicolumn{1}{|c|}{ Mean \pm SD } & SE \\
\hline Item_14 & $4.43 \pm .53$ & .20 \\
\hline Item_15 & $4.71 \pm .49$ & .18 \\
\hline Item_16 & $4.43 \pm .53$ & .20 \\
\hline Item_17 & $4.29 \pm .76$ & .29 \\
\hline Item_18 & $4.43 \pm .53$ & .20 \\
\hline Item_19 & $4.00 \pm 1.0$ & .38 \\
\hline Item_20 & $4.57 \pm .53$ & .20 \\
\hline Item_21 & $4.00 \pm .82$ & .31 \\
\hline Item_22 & $4.29 \pm .76$ & .29 \\
\hline Item_23 & $4.14 \pm .69$ & .26 \\
\hline Item_24 & $4.43 \pm .53$ & .20 \\
\hline Item_25 & $4.29 \pm .49$ & .18 \\
\hline Item_26 & $4.57 \pm .53$ & .20 \\
\hline Item_27 & $4.57 \pm .53$ & .20 \\
\hline Item_28 & $4.29 \pm .76$ & .29 \\
\hline Item_29 & $4.43 \pm .53$ & .20 \\
\hline Item_30 & $4.14 \pm .69$ & .26 \\
\hline Item_31 & $4.43 \pm .53$ & .20 \\
\hline Item_32 & $4.57 \pm .53$ & .20 \\
\hline Item_33 & $4.57 \pm .53$ & .20 \\
\hline Item_34 & $4.57 \pm .53$ & .20 \\
\hline Item_35 & $4.57 \pm .53$ & .20 \\
\hline Item_36 & $4.71 \pm .49$ & .18 \\
\hline Item_37 & $4.43 \pm .79$ & .30 \\
\hline Item_38 & $4.57 \pm .53$ & .20 \\
\hline Item_39 & $4.57 \pm .53$ & .20 \\
\hline Item_40 & $4.00 \pm .58$ & .22 \\
\hline Item_41 & $4.71 \pm .49$ & .18 \\
\hline Item_42 & $4.43 \pm .53$ & .20 \\
\hline & Note: & \\
\hline & & Mean: SD=Standard deviation \\
\hline
\end{tabular}

The limited trial analysis result $(\mathrm{N}=30)$ found that the level of participants understanding on words and sentences used reach $88.83 \%$ and $89.36 \%$ for language suitability. Meanwhile, Aiken content validity coefficient index (CVCI) was .75 to $.93, .85$ for EM-D (EXR-I $=.86$, IJR-I $=.83$, ITR-I $=.83$, IGR-I $=.88)$, and .86 for IM-D $($ TK-I $=.83$, TA-I $=.90$, ES-I = .84). Alpha Cronbach coefficient index for the whole internal consistency reliability was .92 (42 items), .88 for EMD (24 items) and .78 for IM-D (18 items).

Despite the value of KMO MSA ( .68) > .50 (sig. = .00), the value of Bartlett's Test of Sphericity $=8711.57, \mathrm{df}=861$, and alpha $=.05(5 \%)$, there are eight items in anti-image correlation which obtained the value of MSA $<.50$, including item number 2, 7, 14, 19, 21, 23, 29, 40. After all of the eight items were dismissed from the next analysis, it was found that all of the items had anti image value $>.50$. With the value of $\mathrm{KMO} \mathrm{MSA}=.78>.05(\mathrm{sig} .=.00)$ at Bartlett's Test of Sphericity value with Chi-Square $=6920.43$, df $=561$, alpha $=$ $.05(5 \%)$. Therefore, there are no more items should be excluded and the factor analysis assumption has been fulfilled.

In the factor extraction result using principle components analysis method, it was found that all of the items included seven significant factors, had total initial Eigen values $>1(\lambda=$ 8.966) and obtained Varian total percentage $=26.372 \%$. 
TABLE II. FL DISTRIBUTION AFTER ROTATION (ROTATED COMPONENT ANALYSIS)

\begin{tabular}{|l|l|l|}
\hline Factor & \multicolumn{1}{|c|}{ Item } & Total \\
\hline 1 & $\begin{array}{l}\text { item_36, item_30, item_31, item_25, item_32, } \\
\text { item_39, item_33, item_27, item_41, item_28, } \\
\text { item_35, item_42 }\end{array}$ & \\
\hline 2 & $\begin{array}{l}\text { item_1, item_8, item_15, item_22, ítem, } \\
\text { item_10, 24, item_38, item_11, item_12, } \\
\text { item_20 }\end{array}$ & \\
\hline 3 & item_5, item_4, item_6 & 3 \\
\hline 4 & item_9, item_17, item_18, item_13 & 4 \\
\hline 5 & item_16, item_26, item_34 & 3 \\
\hline 6 & item_3 & 1 \\
\hline 7 & item_37 & 34 \\
\hline Total & & 10 \\
\hline
\end{tabular}

Table 2 presents factor loading (FL) distribution of item selection results after rotation (rotated component analysis), and it was found that 30 items achieved FL > .50 (.52 to .87) as a valid item, and four other items were not valid (FL $<.50)$, they were item number 1 (.33), $10(.40), 18(.46)$, and $38(.44)$. The 30 valid items were distributed to EM-D (FL = .59 to .86; 4 item EXR-I, 4 item IJR-I, 4 item ITR-I, and 5 item IGR-I) for 17 items and IM-D (FL $=.52$ to $.87 ; 4$ item TK-I, 6 item TA-I, and 3 item ES-I) for 13 items.

\section{DISCUSSION}

This pilot study was aimed to validate extrinsic and intrinsic motivation on beginner badminton student-athletes. The limited trial, language validation, content validity, internal consistency analysis, CFA were used to analyse reliability and validity of the scale. In the limited trial, it was found that participants' understanding level was $88.83 \%$. Language validation involving three PEJ personals found that the level of suitability was $89.36 \%$. These result inform us that the participants understood the meaning of each item, although there are some words and sentences that were hard to be understood. However, those words and sentences were corrected and revalidated, including the sentence structure. This result highlights that there is language suitability that is used in the cognitive ability sequence scale which is recommended by Whaley [26], including the use of terms in each item and concept to be developed [27]. These two steps play crucial roles to provide a quality psychological scale since a valid and reliable instrument is an instrument that is relevant and match the subject characteristics. Both of the early analysis were strengthened by content validity analysis result by five PEJ. The CVCI of each indicator, dimension, and the whole > $.50(\mathrm{CVCI}>.50)$. This CVCI value shows that the developed items are valid [21], and therefore it reflects a measured behaviour. From the goal perspectives of content validity analysis, it concludes that the developed items are suitable for the aim of the measurement.

As for the CFA results (table 3), 30 valid items were obtained, eight items did not meet the CFA assumptions (MSA $<.5)$ and four items did not have FL <.50. The 30 valid items distributed in each dimension and indicator can be interpreted as items that are able to measure the theoretical latent construct. Conversely for items that do not meet the CFA assumptions and are invalid, interpreted as items that are not able to measure the theoretical latent construct, Ghozali asserts it as an item that has not given perfect confidence that the indicators compiled and developed from the sample represent the actual score in the population [28].

The invalid items can be explained externally and internally. Externally, related to participants' demographics characteristics such as the variation of training period, age level, and gender. Those variables are believed and proven interact with measurement and program treatment [21], and the integrity of the process and the result of measurement [29]. The demographics variable heterogeneity indicates the ability diversity of participants in understanding items. Internally, it is related to the limitation of the researcher ability to construct items that are able to measure the theoretical latent construct.

TABLE III. SELECTION RESULTS AND DISTRIBUTION OF ITEMS FOR EACH DIMENSION AND INDICATOR OF EIMS BASED ON FL VALUE

\begin{tabular}{|c|c|}
\hline $\begin{array}{c}\text { Dimension, Indicator } \\
\text { Item }\end{array}$ & $\begin{array}{c}\text { Factor loading } \\
\text { (FL) }\end{array}$ \\
\hline \multicolumn{2}{|c|}{ EM-D (24 items) } \\
\hline \multicolumn{2}{|c|}{\begin{tabular}{|l|l} 
EXR-I (4 items) &
\end{tabular}} \\
\hline Item 1 & .33 \\
\hline Item 8 & .80 \\
\hline Item 15 & .59 \\
\hline Item 22 & .59 \\
\hline Item 29 & MSA $<.5$ \\
\hline Item 36 & .67 \\
\hline \multicolumn{2}{|l|}{ IJR-I (4 items) } \\
\hline Item 2 & $\mathrm{MSA}<.5$ \\
\hline Item 9 & .69 \\
\hline Item 16 & .64 \\
\hline Item 23 & $\mathrm{MSA}<.5$ \\
\hline Item 30 & .80 \\
\hline Item 37 & .61 \\
\hline \multicolumn{2}{|l|}{ ITR-I (4 items) } \\
\hline Item 3 & .74 \\
\hline Item 10 & .40 \\
\hline Item 17 & .82 \\
\hline Item 24 & .71 \\
\hline Item 31 & .82 \\
\hline Item 38 & .44 \\
\hline \multicolumn{2}{|l|}{ IGR-I (5 items) } \\
\hline Item 4 & .76 \\
\hline Item 11 & .64 \\
\hline Item 18 & .46 \\
\hline Item 25 & .86 \\
\hline Item 32 & .78 \\
\hline Item 39 & .83 \\
\hline \multicolumn{2}{|c|}{ IM-D (18 items) } \\
\hline \multicolumn{2}{|l|}{ TK-I (4 items) } \\
\hline Item 5 & .84 \\
\hline Item 12 & .59 \\
\hline Item 19 & MSA $<.5$ \\
\hline Item 26 & .52 \\
\hline Item 33 & .73 \\
\hline Item 40 & MSA $<.5$ \\
\hline
\end{tabular}


Table III. Cont.

\begin{tabular}{|c|c|}
\hline TA-I (6 items) & \\
\hline Item 6 & .84 \\
\hline Item 13 & .76 \\
\hline Item 20 & .77 \\
\hline Item 27 & .65 \\
\hline Item 34 & .56 \\
\hline Item 41 & .87 \\
\hline ES-I (3 items) & \\
\hline Item 7 & $\mathrm{MSA}<.5$ \\
\hline Item 14 & $\mathrm{MSA}<.5$ \\
\hline Item 21 & $\mathrm{MSA}<.5$ \\
\hline Item 28 & .87 \\
\hline Item 35 & .82 \\
\hline Item 42 & .74 \\
\hline
\end{tabular}

Besides as the factor causing invalid items, the diversity of demographics variable of participant also becomes one of the limitation of this pilot study, which has to be considered and controlled in the future research. In the methodological aspects, it interacts with the quality of process and the result of measurement. Theoretically, motivation as one of important variables in sport [30] is a combination of personality factors, social factors, and cognitive process [31], which is correlated to other psychological parameters related to the improvement of learning and performance [32], and has dynamic and fluctuate characteristics that its development should be detected from the beginning through various psychological strategies to be a stable and robust dynamic property in sport motivation.

Besides content and construct validation, the scale was also reliable. It obtained Alpha Cronbach index coefficient $>.70$ (.78 to .92$)$ as the whole (42 items) or for the value of EM-D = .88 (24 items) and the value of IM-D $=.78$ (18 items). The value of coefficient index shows the accepted level of internal consistency [33-34], and categorized as an instrument that has a good and very good reliability [35]. Thus, EIMS is proven to be valid and reliable, and this reflects also valid and reliable measurements that will become "a precursor to the understanding of any psychological construct" [36] and methodologically, careful measurements are needed to assess, understand, and predict the influence of each psychological construct on human behaviour [37,38].

\section{CONCLUSION}

The sequences of the process of validation analysis found that there were 30 items that can be used to measure the intrinsic and extrinsic motivation of the badminton beginner student-athletes in the process of badminton training. 17 items represent EM-D (4 item EXR-I, 4 item IJR-I, 4 item ITR-I, 5 item IGR-I) and 13 items represent IM-D (4 item TK-I, 6 item TA-I, and 3 item ES-I). The revalidation has to be conducted to the 30 items by considering the characteristics of the participants to improve validity and reliability of the scale, to build the psychometric properties, and to decrease the validity limitation in this pilot study.

\section{REFERENCES}

[1] R.J. Vallerand, "Intrinsic and extrinsic motivation in sport and physical activity," In Tenenbaum and Eklund (3rd. Eds.). Hand Book of Sport Psychology. New Jersey: John Wiley \& Sons, Inc., 2007, pp. 59-83.

[2] L.G. Pelletier, M.A. Rocchi, R.J. Vallerand, E.L. Deci, and R.M. Ryan, "Validation of the revised Sport Motivation Scale (SMS-II)," Psychology of Sport and Exercise, vol. 14, pp. 329-341, 2013.

[3] J.A.M. Murcia, E.C. Gimeno, and D.G. Cuntre-Coll, "Young athletes" motivational profiles," Journal of Sport Science and Medicine, vol. 6, pp. 172-179, 2007.

[4] G.C. Roberts, D.C. Treasure, and D.E. Conroy, Understanding the dynamics of motivation in sport and physical activity. In Tenenbaum and Eklund (Eds.). Handbook os sport psychology. New Jersey: John Wiley \& Sons, Inc., 2007, pp. 3-30.

[5] J.F. Sallis, J.J. Prochaska, and W.C. Taylor, "A review of correlates of physical activity of children and adolescents," Medicine and Science in Sports and Exercise, vol. 32, pp. 963-975, 2000.

[6] E.L. Deci and R.M. Ryan, Instrinsic motivation and self determination in human behavior. New York: Plenum Press, 1985.

[7] E.L. Deci and R.M. Ryan, "The 'what' and 'why' of goal pursuits: human need and the self determination of behavior," Psychological Inquiry, vol. 11, pp. 1024-1037, 2000.

[8] C. Li, M. Kawabata, and L. Zhang, "Validity and reliability of the sport motivation scale-II for Chinese athletes," International Journal odf Sport and Exercise Psychology, pp. 1-14, 2016.

[9] E.L. Deci and R.M. Ryan, "Self-determination theory: A Macrotheory of human motivation development, and health," Canadian Psychology, vol. 49, no. (3), pp. 182-185, 2008

[10] D.G. Cutre and A. Sicilia, "Motivation and exercise dependence: A study based on self-determination theory," Research Quarterly for Exercise and Sport, vol. 83, no. (2), pp. 318-329, 2012.

[11] K.M. Kingston, C.S. Horrocks and S. Hanton, "Do multidimensional intrinsic and extrinsic motivation profiles discriminate between athlete scholarship status and gender?" European Journal of Sport Science, vol. 6, no. (1), pp. 53-63, 2006.

[12] S.R. Wininger, "Self-determination theory and exercise behavior: An examination of the psychometric properties of the exercise motivation scale," Journal of Spplied Sport Psychology, vol. 19, no. (4), pp. 471486, 2007.

[13] V. Barkoukis, H. Tsorbatzoudis, G. Grouios, and G. Sideridis, "The assess- ment of intrinsic and extrinsic motivation and amotivation: Validity and reliability of the Greek version of the academic motivation scale," Assessment in Education: Principles, Policy, \& Practice, vol. 15, no. (1), pp. 39-55, 2008.

[14] L.G. Pelletier, M. Rocchi, C. Guertin, C. Hebert, and P. Sarrazin, "French adaptation and validation of the sport motivation scale-II (Echelle de motivation dans les sport-II)," International Journal of Sport and Exercise Psychology, pp. 1-18, 2017.

[15] L.G. Pelletier, M.S. Fortier, R.J. Vallerand, K.M. Tuson, N.M. Briere, and M.R. Blais, "Toward a new measure of intrinsic motivation, extrinsic motivation, and amotivation in sports: The Sport Motivation Scale (SMS)," Journal of Sport \& Exercise Psychology, vol. 17, pp. 3535, 1995.

[16] M.P. Martens and S.N. Webber, "Psychometric properties of the sport motivation scale: An evaluation with college varsity athletes from the U.S.," Journal of Sport and Exercise Psychology, vol. 24, pp. 254-270, 2002.

[17] H.A. Pineda-Espejel, E. Alarcón, Z. López-Ruiz, M. Trejo, and C. Chávez, "Propiedades psicométricas de la Escala de Motivación en el Deporte revisada (SMS-II) adaptada al español hablado en México [Psychometric properties of the revised sport motivation scale (SMS-II) adapted to the Spanish spoken in Mexico]," RICYDE. Revista Internacional de Ciencias del Deporte, vol. 12, pp. 107- 120, 2016.

[18] Y. Hidayat, "Struktur faktor motivasi olarhaga: Analisis perspektif teori determinasi diri dan implikasinya dalam penelitian pendidikan jasmani dan olahraga," Jurnal Pendidikan Jasmani dan Olahraga, vol. 4, no. (2), pp. 107-121, 2010. 
[19] Y. Hidayat and Sukadiyanto, "Instrumen strategi multiteknik mental atlet usia 11-13 tahun," Jurnal Iptek Olahraga, vol. 14, no. (3), pp. 268287, 2012.

[20] B. Johnshon and L. Christensen, Educational research (4th. ed.) London: SAGE, 2012

[21] J.R. Thomas, J.K. Nelson, and S.J. Silverman, Research method in physical activity (5th. Eds). New Jersey: Human Kinetics, 2011.

[22] L.D. Goodwin, "The role of factor analysis in the estimation of construct validity," Measurement in Physical Education and Exercise Science, vol. 3, no. (2), pp. 85-100, 1999.

[23] R.J. Gregory, Psychological testing: History, principles, and application. Boston: Pearson, 2007.

[24] G. Sporis, I. Jukic, L. Milanovic, and V. Vucetic, "Reliability and factorial validity of agility tests for soccer players," Journal of Strength and Conditioning Research, vol. 24, no. (3), pp. 679-686, 2010

[25] A.C. Lacy, Measurement and evaluation in physical education and exercise science. Boston: Benjamin Cummings, 2011.

[26] D.E. Whaley, "A Life Span Developmental Approach to Studying Sport and Exercise Behavior," In G. Tenenbaum and R.C. Eklund (Eds) Handbook of Sport Psychology (3rd ed.). Hoboken. NJ: Jhon Wiley and Sons, 2007, pp. 645-661.

[27] R.E. Stadulist, M.J. MacCracken, T.A. Eidson, and C. Severance, "A children's form of the compe-titive state anxiety inventory: The CSAI2C," Measurement in Physical Education and Exercise Science, vol. 6, pp. 147-165, 2002.

[28] I. Ghozali, Aplikasi analisis multivariat, dengan program SPSS Semarang: Badan Penerbit Universitas Dipenogoro, 2009.

[29] Y. Hidayat and B. Hambali, Confirmatory factor analysis of the self confidence scale among beginner badminton child-athletes: A pilot study. 2nd International Conference on Sports Science, Health and Physical Education (ICSSHPE 2017), Bandung: 951-956, 2017.

[30] J. Manouchehri, F. Tojari, and S. Soltanabadi, "Validity and reliability of measurement instrument for sport motivation scale in professional atheles in TeamSport of Iran," Journal of Psychiatry, vol. 18, no. (2), pp. $1-4,2015$.

[31] R. Paic, A. Kajos, B. Meszler, and G. Prisztoka, "Mental aspect of sport performance validation of the Hungarian Sport Motivation Scale $(\mathrm{H}-$ SMS) Cognition, Brain, Behavior," An Interdisciplinary Journal, vol. XXI, no. (4), pp. 275-29, 2017.

[32] Y. Hidayat and D. Budiman, "The influence of self-talk on learning achievement and self confidence," Asian Social Science, vol. 10, no. (5), pp. 186-193, 2014.

[33] E.T.C. Lam and J.J. Zhang, "The development and validation of a racquet-ball skills test battery for young adult beginners," Measurement in Physical Education and Exercise Science, vol. 6, no. (2), pp. 95-126, 2002.

[34] C. Li, M. Kawabata, and L. Zhang, "Validity and reliability of the sport motivation scale-II for Chinese athletes," International Journal odf Sport and Exercise Psychology, pp. 1-14, 2016.

[35] S. Azwar, Penyusunan skala psikologi. Yogyakarta: Pustaka Pelajar, 2012.

[36] J.L. Fleiss, Statistical methods for rate and proportions. 2nd Ed. New York: Wiley, 1981.

[37] R.B. Clancy, M.P. Herring, and M.J. Campbell, "Motivation measures in sport: A critical review and bibliometric analysis," Prontier in Psychology, vol. 8, no. (348), pp. 1-2, 2017.

[38] R.B. Clancy, M.P. Herring, T.E. MacIntyre, and M.J. Campbell, "A review of competitive sport motivation research," Psychology of Sport and Exercise Review, vol. 27, pp. 232-242, 2016. 